\title{
FINANCIAL RESULTS OF STARBUCKS IN CHENGDU CITY, CHINA
}

\section{ФIНАНСОВI РЕЗУЛЬТАТИ КОМПАНIÏ STARВUCKS У М. ЧЕНДУ, КИТАЙ}

Summary. With deepening reforms and the rapid development of the Chinese economy, the Chinese market has attracted enterprises from abroad. Thanks to a new business model, an improved business philosophy, excellent service and excellent quality, Starbucks has gained a good reputation among the Chinese consumers and gained a high level of profitability, and became an example for many enterprises of this network. The article reviews the financial performance of Starbucks over the past five years as the main subject of research and analyzes the financial statements of Starbucks in Chengdu using the basic method of financial analysis. An analysis of the financial statements of Starbucks Chengdu over the past five years showed that although the company was profitable and built up a good reputation in just a few years, there are still some problems in the business process, namely problems in financial management. Therefore, given these problems, proposals and prospects for the future are put forward.

Keywords: Starbucks, financial indicators, costs of expansion of production, diversification, methods of financial analysis, profit, taxes.

Formulation of the problem. In the implementation of production and financial activities of enterprises a large number of interrelated material, labor and financial resources are involved. The main goal of any business is to get a positive financial result and find ways to increase it.

In the market environment of conducting business activities, enterprises should ensure themselves sustainable economic development, taking into account the peculiarities of the market environment and effectively conduct business process, increase the level of self-financing and innovative improvement of their activity. In such circumstances, the study of the dialectic of the category of financial result, its relationship and interaction with other economic indicators, and formation on this basis of stable prerequisites for increasing profitability, competitiveness and ensuring stable development of economic activity of the enterprise in the long-term perspective are of considerable scientific and practical value.

Analysis of recent research and publications. Significant contribution to the study of theoretical foundations of the category of financial result was made by such leading foreign and domestic scientists: I.O. Blank, O.V. Budko, F.F. Butynets, A.G. Zagorodnii, G.L. Voznyuk, S.L. Londar, O.V. Tymoshenko, R.V. Skaliuk and other scientists. But despite the considerable scientific achievements of these scientists on the subject under study, some problematic issues require more detailed study and resolution, since economists often consider the question of profit management rather than the financial results of the enterprise $[1 ; 5 ; 3 ; 9 ; 7]$.

Problem statement. Despite the interest of scientists in the selected issues, the study of the category «financial result», as a multifaceted indicator of the effectiveness of the enterprise, does not lose relevance. Therefore, the study of the financial result on the example of Starbucks deserves further attention.

The main material research. With the growth and development of China's economy, more and more excellent foreign enterprises come to China. Starbucks, a global household name, came to China and was quickly accepted, loved and brought its own brand fashion culture. Starbucks' success in China has become a model for many global chains and inspirational books. Since the reform and opening up, China's economy has been rapidly developed, local enterprises are growing up day by day. With the development of global integration, more and more Chinese enterprises have set their sights on the international market, and at the same time, China has gradually formed a huge market that makes the whole world excited. Faced with such reality, many state-owned and private enterprises in China are eager to expand outward, and there are many problems in their development process, not only the lack of professional management knowledge, especially the lack of attention to finance $[12 ; 16]$.

As a result, the control ability of the enterprise is low, so that the enterprise cannot continue to develop well. This paper will read the secret language from the financial statements of Starbucks Chengdu company, and summarize the methods and means of financial control by discussing the operation mode and applying the relevant knowledge of financial statement analysis, in the hope that relevant industries in China, especially the tertiary industry, can get some enlightenment from it.

Chapter 1. Starbucks company profile.

1.The introduction of Starbucks

Starbucks coffee company, founded in 1971, is the world's leading specialty coffee retailer, roaster and brand owner. Its retail products include some of the world's best coffee beans.

There are more than 30 kinds, also it provides a variety of functions and styles of coffee machines, coffee cups and other goods. Starbucks was bought by its chairman, Howard Schultz, in 1987, 
and then the company has gone from bad to better. In June 1992, Starbucks successfully listing as the first specialty coffee company. As of 2013, it has more than 13000 stores worldwide with more than 145000 employees [8; 11].

Starbucks Corporation is among the giants that see great potential in China and hopes to make the country its largest international market outside the U.S. in the near future. Starbucks opened its first store in Taiwan in March 1998, and its first store in mainland China in Beijing in January 1999. According to the statistics of 2013, Starbucks has opened nearly 700 stores in China, including Hong Kong, Macao and Taiwan, about 560 of which are in mainland China. At the end of 2005, Starbucks established Starbucks Enterprise Management (China) Co., Ltd. in Shanghai, which is mainly responsible for the strategic development, market development and operation of Starbucks in greater China. Since its establishment at the end of 2005, Starbucks in Chengdu has opened 41 stores in Chengdu and Chongqing, and opened its first store in Wuhan in 2009 [13].

2. The background of Starbucks brand.

Firstly, the growth of Starbucks. Starbucks is the name of a world-famous coffee chain. Gerald Baldwin, Zev Siegl and Gordon Bowker opened their first specialty coffee and spice store, Starbucks, at Seattle's Pike Place Market in 1986. Howard Schultz joined Starbucks in 1982. He used his personal experience to change Starbucks' business philosophy and achieve success. In $1986 \mathrm{Mr}$ Schultz paid to restructure Starbucks, transforming it into an Italian coffeehouse and running it entirely on his own terms. Over the past two decades, Starbucks has grown, first, in the United States and then globally. Superficially, Starbucks' star journey is to sell coffee, but in fact, it provides people with an «experience» environment while selling coffee. It is these elements that convey Starbucks' corporate culture and core values of the brand to consumers and bring them unforgettable consumption experience [15].

Second, Core brand value of Starbucks

a. Experimental marketing

It is thought in Starbucks that its product is not just a cup of coffee, but the whole experience in a coffee shop. Starbucks has made full use of «experience» as its winning marketing tool. That is, it is an experience at all moments of contact between the enterprise and the customer. So, experience is a lifestyle change. It is this desire for lifestyle change that has created Starbucks' core brand value. One of Starbucks' main competitive strategies is to communicate with customers in the coffee shop, and pay special attention to the communication with customers [14].

b. One-to-one personalized service

In the stores of Starbucks, the communication and communication between customers and staff are ubiquitous, which can be felt both in the store and in the after-sales service. With the experience as the platform, the experience will be fully developed through specific details, so that the customers as the protagonist can fully show their personality and experience a completely different experience.

3. The development of Starbucks in China

A. Development analysis of Chinese coffee market

It has been more than 100 years since the introduction of coffee in China. Coffee production in China has experienced a tortuous course of development. From the peak period of development in the 1950s to the 1960s, the production was reduced, until the 1980s, with the development of China's economy, coffee production recovered rapidly. Since the beginning of the 21 st century, with the development of China's economy and the continuous improvement of people's quality of life, coffee consumption has increased rapidly, with the annual market growth rate reaching 10\%-15\%. Based on the global consumption of 4 million tons, China's coffee consumption market still has much space and potential. By 2012, the consumption will reach 120,000 tons, the retail sales of the market will reach tens of billions CNY, which let us see a huge market, a huge profit. Pablo Dubois, head of operations at the international coffee organization (ICO), sees great potential in the Chinese market. «The Chinese market is already showing signs of following this trend, so China will become an important coffee consumer market in the world.»

B. Analysis of the Chinese consumers

With the further recognition of coffee in China, more and more consumers will believe in it. According to a survey of inland cities, 32 percent of urban residents drink coffee. There are also a lot of potential consumers who are influenced by their friends or who like the environment of the coffee shop. There are also a large number of returnees who have brought new lifestyles and ideas with them. Under their guidance, new people will also like coffee. With people's understanding of coffee and coffee culture, more and more consumers will come into the store to consume. Young and middle-aged people will become the mainstream consumer group. The young people born in the 1980s are very quick to respond to and accept new things. They are interested in and willing to try foreign food culture [17].

C. The market positioning of Starbucks

Starbucks will own positioning independently of the family, away from the office of the «third space», and its target market is paying attention to enjoy, leisure rich small endowment emotional appeal of urban white-collar workers, in the coffee shop, the music in Starbucks is from already developed with independent intellectual property rights, all of these meet the fashion, trendy, the pursuit of fashionable white-collar class. Moreover, the provision of network has promoted the growth of «third space». The wireless Internet area set up in the coffee shop provides convenient services for mobile office and tourists. Starbucks with its unique way of experience, let the target customers focus on their own favorite, suitable for their own taste, in line with their own personality of coffee [4]. In addition, excellent service, excellent quality, standard operation, on-site preparation and continuous launch of new products are important factors for its successful market positioning and rapid development in a country where tea is a traditional beverage.

D. Starbucks' competitors in the Chinese market

Coffee brand has a lot of the mainland market, such as earlier Taiwan island coffee, Japan's pot of coffee, as well as the new Pacific, Costa coffee Starbucks as the most powerful competitors, comprehensive analysis, Starbucks is facing competitors can be roughly divided into two forms: one kind is the same independent local coffee shop with the brand identity in the coffee chain and into the market in succession. The other is convenience stores, fast food restaurants and vertical coffee machines. But there is still a long way to go before the Chinese, who are accustomed to tea, can drink coffee on a regular basis.

4. The prospect of Starbucks in the Chinese market

Due to the huge potential of the current Chinese market and the gradual formation of its own coffee culture, the coffee market is expanding at a rate of more than $30 \%$ per year, so there is a huge room for value added in the Chinese coffee market.

With the rapid development of China's economy, the improvement of education and lifestyle, more and more people will go to coffee shops. At that time, coffee will be closely connected with our life, no longer just a drink, but gradually become the necessity of life, but also closely linked with fashion, taste, reflect the high 
quality of modern life. Both friends and business meetings can be held in the café [2].

China is Starbucks' second-largest market now after the U.S. Starbucks will continue to increase its investment in China. Because of its popularity and business philosophy has been accepted and recognized by the domestic people.

5. Problems in the development of Starbucks in China

Since its first store in Beijing in 1999, Starbucks has opened 700 stores in China, including Hong Kong, Macao and Taiwan. The rapid expansion has made Starbucks popular and profitable in China, but it has also created a series of unprecedented problems.

A. Rapid expansion leads to excessive capital occupation.

Taking the Chengdu company as an example, the first store opened in the first floor of Wangfujing shopping mall. Due to its good location, large crowds and being the first store in Chengdu at that time, the opening made Starbucks the sales champion of single store in mainland China. Shocked by the mainland's spending power, the company accelerated the pace of opening stores in Chengdu over the next two years. Throughout the Starbucks stores in mainland China, they are all located in places with large crowd flow, uniform decoration and equipment, high rent and large investment in fixed assets. In order to achieve perfection, a lot of equipment and decoration materials are shipped from the United States [6].

This makes each branch invests a lot of capital, make the capital of the company takes up too much, which are also a big risk in management. Chengdu company is compared with XX yuan coffee shop, another successful coffee retail chain in Chengdu.

It can be seen that the local coffee chain with good reputation in Chengdu has opened 15 stores in 14 years, while Starbucks has opened 24 stores in 7 years. The cost of the decoration and equipment of the single store is also much higher, which is also related to the different requirements and standards of the company.

Many of Starbucks' equipment and ingredients are purchased globally in order to ensure its first-class quality, which also increases the cost and capital consumption. With the increase of stores, rent, personnel management, the purchase of fixed assets and other costs come with it, which is a heavy burden for the newly established companies, greatly occupies the capital, and also increases the operational risk. This is a more prominent problem of Chengdu company at present [10].

B. The cost is too high.

In order to ensure the company's high-quality service and good corporate culture, the company conducts more training for employ- ees, but the training input increases rapidly every year due to the excessive turnover of personnel.

In addition, in order to ensure the quality of coffee, many main ingredients are purchased and transported from the United States, which makes the transportation cost of each branch account for a large proportion of the total cost. It can be seen from the financial statements of these years that the main business cost accounts for the proportion of the revenue in the cost of transportation [18].

All of them are lower than the proportion of the period expenses in the income, and the period expenses account for more than $50 \%$ of the main business income, which makes the net profit drop significantly and also leads to the decline of the net interest rate on sales. Take the income and cost of Chengdu company from 2016 to 2018 as an example.

As can be seen from the above table, the period expenses of Chengdu company account for a large proportion of the income. Further analysis shows that transportation cost and management cost account for a large proportion in the period.

This is because some raw materials are shipped directly from the United States, which adds to the cost. In addition, with the increase of stores, the training cost of employees has also been greatly increased, which makes the cost of the period to remain high, and now it has become a problem that needs to be improved immediately.

C. The slow development of new products will affect the sales revenue.

Compared with the same industry, new product development of Starbucks is performed not good enough, so more than ten years of coming to China its varieties changed little and the pace is a little slower than of the other coffee chains, so that influences the choice of consumers. At present, the product is classic coffee, Starbucks Frappuccino, coffee and tea, and setting up a little change, everyone is familiar with its variety and taste. Compared with the local XX yuan coffee shop, it is also a coffee chain. You can not only taste the authentic coffee, but also eat a variety of drinks and the current trend of the meal, product innovation, so that consumers have more choices. At present, many competitors enter the market in succession, and there are some new drinks or various dairy products to replace, these are potential threats for Starbucks. All these problems occurred in the development process of China. Only Starbucks can develop better and go further in China by timely adjustment and improvement to make localization do better.

Chapter 2. Financial analysis of Starbucks in Chengdu company.

Financial analysis plays an important role in enterprise financial management. It is an important basis for evaluating the business

Store comparison between the two companies

\begin{tabular}{|l|c|c|c|c|}
\hline \multicolumn{1}{|c|}{ Name } & Date & Number & Site scope & Cost of decoration and equipment \\
\hline Starbucks & 2006 & 24 & Third ring road & $70-90$ \\
\hline XX yuan & 1998 & 15 & Third ring road & 50 \\
\hline
\end{tabular}

Sources: own research

Table 2

Sales of Chengdu company in three years

\begin{tabular}{|l|c|c|c|}
\hline \multicolumn{1}{|c|}{ Indicators } & $\mathbf{2 0 1 6}$ & $\mathbf{2 0 1 7}$ & $\mathbf{2 0 1 8}$ \\
\hline Main business income & 87260565 & 99914409 & 173851072 \\
\hline Main business cost & 23753796 & 32552488 & 56641329 \\
\hline Proportion of main business revenue & $27.21 \%$ & $32.58 \%$ & $32.58 \%$ \\
\hline Period expense & 5190852 & 60159178 & 98469354 \\
\hline Proportion of main business revenue & $59.47 \%$ & $60.21 \%$ & $56.64 \%$ \\
\hline
\end{tabular}

Sources: own research 
performance and financial status of enterprises. By analyzing the financial status of the enterprise, the operating ability, profitability, solvency and growth ability of the enterprise can be understood, which is conducive to the objective evaluation of the operating performance and financial status of the managers and their related personnel $[19 ; 20]$.

1. Financial index system analysis

A. Historical comparative analysis

Starbucks in Chengdu company has been working hard since its establishment and has gradually opened the Chengdu market through years of hard work. This paper lists the following specific financial indicators after sorting and calculating the financial statements of Chengdu company in the past five years.

It shows the weak solvency. The financial security of a company is mainly reflected by the solvency of the company, that is, whether it can pay the debts due in full on time.

Therefore, paying attention to the effectively improve the company's debt paying ability is not only a guarantee to safeguard the rights and interests of the company's creditors, but also an objective requirement for the company to survive and continue to develop in the market competition. The solvency of Starbucks corporation is carried out from two aspects: short-term solvency and long-term solvency [17].

2. Prospect analysis

Through introduction to the Chengdu company and the company five years the results of tracking analysis, we know that Starbucks was founded in 2006 in Chengdu after management center. After five years of operation profit, this short into make profits, this is very rare in foreign fast away industry, suggesting a Starbucks not only accepted by people in mainland China and fell in love with it, the development of considerable scale and enter the benign development. Firstly, it takes unique corporate culture and excellent operation mode have conquered the inland areas where tea is the main drink, and its advantages and potential are huge. During the operation in Chengdu, the company has made many local adjustments in terms of operation, management and service, so as to make Starbucks more regional and human. After having this good foundation, Chengdu company opens a large number of new stores according to the mode of headquarters, and has gone deep into the second and third tier cities, rooted in the inland. From these years of sales revenue can be seen, each year than the previous year growth is: $36 \%, 42 \%, 14 \%, 74 \%$, it is a high speed growth development. Secondly, in recent years, the management of Chengdu company has been replaced, from the original headquarters to the present peer recommendation, competition, and the average age of about 30 years old, young people's enthusiasm, vitality, professionals in the industry, all these make the company management, professional and other aspects of talent matching reasonable and perfect. However, in this development process, we found some points that are worth noting:

Conclusions from the study. Through the analysis of the financial statements of Chengdu company in the past five years, we can see that although the company has realized the overall profit and created a good reputation in just a few years, there are still some problems in the development process from both financial management and operation. The following conclusions can be drawn:

1. Rapid expansion leads to excessive capital occupation and excessive outflow of investment cash

Due to the rapid expansion of Chengdu company after entering the Chengdu market, the rapid development of the company has strained the company's cash flow, and the overall development of the company is not good. Although the indicators of debt paying ability, operation ability and development ability have been increasing year by year, it can be seen from the balance sheet that the company's accounts receivable, inventory and short-term liabilities are relatively low, and the investment of fixed assets is too significant for the company, the outflow of investment cash flows is too large and the inflow is too small.

2. High proportion of fixed assets leads to high cost

As the investment in fixed assets increases with the opening of stores, the asset-liability ratio is also high, which is very dangerous for the company to operate. It can be seen from the income statement that the company's main business costs and operating expenses account for a high proportion and grow rapidly year by year, which greatly reduces the net interest rate.

3.The main business cost is too high, the sales gross profit growth is slow, resulting in slow sales revenue growth Chengdu company from the beginning of its establishment to the product update speed is too slow compared with the same industry, which is far from meeting the needs of consumers. Since the establishment of the company, it has provided consumers with the coffee and cakes, which is far behind the local coffee chain in terms of product variety and update speed. In this way, it will create management centers for long-term training trainees to provide to new stores. These training expenditure, personnel salary and so on all increased the expense. Suggest of the company change the marketing strategy, can slow down the pace of store opening. Focus on the operation of high-quality stores, improving the efficiency of a single store, so as reducing expenses, increases the net cash flow of the investment activities. Lower store rents, sign long-term rental contracts with real estate developers, or buy prime real estate, which can be used as long-term investment.

Chengdu company of Starbucks in the last five years of specific financial indicators

Table 3

\begin{tabular}{|l|c|c|c|c|c|}
\hline \multirow{2}{*}{\multicolumn{1}{|c|}{ Indicators }} & \multicolumn{5}{c|}{ Years } \\
\cline { 2 - 6 } & $\mathbf{2 0 1 4}$ & $\mathbf{2 0 1 5}$ & $\mathbf{2 0 1 6}$ & $\mathbf{2 0 1 7}$ & $\mathbf{2 0 1 8}$ \\
\hline Liquidity ratio & 0.23 & 0.23 & 0.44 & 0.67 & 0.56 \\
\hline Quick ratio & 0.15 & 0.13 & 0.33 & 0.58 & 0.46 \\
\hline Equity ratio & 5.16 & 5.64 & 2.7 & 0.88 & 1.59 \\
\hline Net profit margin on sales & 1.2 & 0.92 & 8.2 & 2.45 & 3.32 \\
\hline Operating profit ratio & 0.33 & 0.48 & 8.63 & 1.44 & 5.01 \\
\hline Rate of return on total assets & 1.17 & 1.38 & 20.06 & 6.63 & 11.01 \\
\hline Net assets income rate & 2.05 & 6.18 & 85.2 & 2.14 & 23.52 \\
\hline Turnover of total capital & 1.33 & 1.95 & 2.3 & 2.72 & 3.11 \\
\hline
\end{tabular}

Sources: own research 
Through the above overall analysis, we can see that the development of Chengdu company is good. From the company's fiveyear financial report, we can see that the company's revenue and profit are both on the rise. According to the theory, the development of a company should go through a period of establishment, maturity, decline and exit. The reality is so inconsistent with the ideal. On the whole, the main problems of the company are that the rapid expansion leads to excessive capital occupation, unreasonable asset structure, excessive cost and expense, and slow new product development affects the revenue growth. As for Starbucks with a good market foundation, only facing the deficiencies in its operation and taking appropriate measures can better maintain and extend its glorious maturity period and create more enterprise value.

\section{References:}

1. Amihud, Y. (2002). Illiquidity and stock returns: Cross-section and time-series effects. Journal of Financial Markets, 5, 31-56.

2. Botosan, C.A., \& Harris, M.S. (2000). Motivations for a change in disclosure frequency and its consequences: An examination of voluntary quarterly segment disclosures. Journal of Accounting Research, 38, 329-353.

3. Brown, S., Hillegeist, S.A., \& Lo, K. (2009). The effect of earnings surprises on information asymmetry. Journal of Accounting and Economics, 47, 208-225.

4. Butler, M., Kraft, A., \& Weiss, I.S. (2007). The effect of reporting frequency on the timeliness of earnings: The cases of voluntary and mandatory interim reports. Journal of Accounting and Economics, 43, 181-217.

5. Chan, Kalok, Wilson H.S. Tong, and Shaojun Zhang, 2015, Trading restriction, tick size and price discovery: Evidence from a natural experiment in China, Working Paper.

6. Fu, R., Kraft, A., \& Zhang, H. (2012). Financial reporting frequency, information asymmetry, and the cost of equity. Journal of Accounting and Economics, 54, 132-149.

7. Gigler, F., Kanodia, C., Sapra, H., \& Venugopalan, R. (2014). How frequent financial reporting can cause managerial short-termism: An analysis of the costs and benefits of increasing reporting frequency. Journal of Accounting Research, 52, 357-387.

8. Kucher O., Pokotylska N. (2016) Marketing management in the system of agricultural enterprises management. Podilian bulletin: agriculture, engineering, economics. P. 128-134. 2016. http://188.190.33.55:7980/jspui/bitstream/123456789/336/1/ PB-25-15.pdf (accessed 26 March 2020).

9. Kucher Oleg. (2017) Problems of management and marketing in the enterprises activity of agriculture, SCIENTIFIC ACHIEVEMENTS IN AGRICULTURAL ENGINEERING AGRONOMY AND VETERINARY MEDICINE Vol. 1, No. 1, pp. 31-41 ISBN 978-83-65180-17-9. 2017. http://188.190.33.55:7980/jspui/bitstream/123456789/12/1/Problems\%20Of\%20Management $\% 20$ And\%20Marketing\%20In\%20Theenterprises\%20Activity\%20 Of\%20Agriculture.pdf (accessed 26 March 2020).

10. Leftwich, R.W., Watts, R.L., \& Zimmerman, J.L. (1981). Voluntary corporate disclosure: The case of interim reporting. Journal of Accounting Research, 19, 50-77.

11. Mandych O., Mykytas A., Melnyk M., Girzheva O., Kalinichenko S. (2020) Financial Condition of the Development of the Market of Renewable Energy Sources. In: Wróbel M., Jewiarz M., Szlęk A. (eds) Renewable Energy Sources: Engineering, Technology, Innovation. Springer Proceedings in Energy. Springer, Cham, pp. 939-951. https://link.springer.com/chapter/10.1007/978-3030-13888-2 90\#citeas (accessed 28 March 2020).

12. Melnyk M., Zabolotnyy S. (2017) Essence of the financial state of the enterprise. Actual problems of agrarian economy: theory, practice, strategy. 2017 P. 262-265. http://188.190.33.55:7980/jspui/bitstream/123456789/6916/1/120-123.pdf (accessed 29 March 2020).

13. Morck, R., Yeung, B., \& Yu, W. (2000). The information content of stock markets: Why do emerging markets have synchronous stock price movements? Journal of Financial Economics, 58, 215-260.
14. Schipper, K. (1981). Discussion of voluntary corporate disclosure: The case of interim reporting. Journal of Accounting Research, 19, 85-88.

15. Verrecchia, R. E. (1990). Information quality and discretionary disclosure. Journal of Accounting and Economics, 12, 365-380.

16. Yee, K.K. (2004). Interim reporting frequency and financial analysts' expenditures. Journal of Business Finance \& Accounting, 31, 167-198.

17. Zabolotnyy S., Melnyk M. (2018) The Financial Efficiency of Biogas Stations in Poland. In: Mudryk K., Werle S. (eds) Renewable Energy Sources: Engineering, Technology, Innovation. Springer Proceedings in Energy. Springer, Cham, pp. 83-93. https://link.springer.com/chapter/10.1007/978-3-319-72371-6_9 (accessed 27 March 2020).

18. Melnyk M.I. (2017) Modeling and estimation of financial condition of agricultural agroformations of Ukraine and Poland [Electronic resource]/M.I.Melnyk//Economic Bulletin of theZaporizhzhya State Engineering Academy. - 2017. - Vip. 5(11).- Access mode: http:// www.irbis-nbuv.gov.ua/cgi-bin/irbis_nbuv/cgiirbis_64.exe?I21DB$\mathrm{N}=\mathrm{LINK} \& \mathrm{P} 21 \mathrm{DBN}=\mathrm{UJRN} \& Z 21 \overline{\mathrm{ID}}=\& \mathrm{~S} 21 \mathrm{REF}=10 \& \mathrm{~S} 21 \mathrm{CN}-$ $\mathrm{R}=20 \& \mathrm{~S} 21 \mathrm{STN}=1 \& \mathrm{~S} 21 \mathrm{FMT}=\mathrm{ASP}$ meta\& $21 \mathrm{COM}=\mathrm{S} \& 2$ S21P03=FILA=\&2_S21STR=evzdia_2017_5(1)_36 (accessed $2 \overline{6}$ March 2020).

19. Melnyk M.I. (2017) Ukraine's innovation attractiveness based on the Global Innovation Index. Economic Bulletin of Zaporizhzhya State Engineering Academy. Zaporizhzhia. Vol. 4(10). P. 123-128.

20. Chornuy G.M., Yastreb M.P., Kucher O.V. Nowadays approach to the content of management activities in agro-formations. Agrarian Information Research and Production Journal: Science and Production No. 1-3.-Kiev Agroincom. pp. 80-84.2011.http://library.tneu.edu.ua/ libsearch/page_lib.php (accessed 26 March 2020).

\section{Jimepamypa:}

1. Amihud, Y. (2002). Illiquidity and stock returns: Cross-section and time-series effects. Journal of Financial Markets, 5, 31-56.

2. Botosan, C.A., \& Harris, M.S. (2000). Motivations for a change in disclosure frequency and its consequences: An examination of voluntary quarterly segment disclosures. Journal of Accounting Research, 38, 329-353.

3. Brown, S., Hillegeist, S.A., \& Lo, K. (2009). The effect of earnings surprises on information asymmetry. Journal of Accounting and Economics, 47, 208-225.

4. Butler, M., Kraft, A., \& Weiss, I.S. (2007). The effect of reporting frequency on the timeliness of earnings: The cases of voluntary and mandatory interim reports. Journal of Accounting and Economics, 43, 181-217.

5. Chan, Kalok, Wilson HS Tong, and Shaojun Zhang, 2015, Trading restriction, tick size and price discovery: Evidence from a natural experiment in China, Working Paper.

6. Fu, R., Kraft, A., \& Zhang, H. (2012). Financial reporting frequency, information asymmetry, and the cost of equity. Journal of Accounting and Economics, 54, 132-149.

7. Gigler, F., Kanodia, C., Sapra, H., \& Venugopalan, R. (2014). How frequent financial reporting can cause managerial short-termism: An analysis of the costs and benefits of increasing reporting frequency. Journal of Accounting Research, 52, 357-387.

8. Kucher O., Pokotylska N. (2016) Marketing management in the system of agricultural enterprises management. Podilian bulletin: agriculture, engineering, economics. C. 128-134. 2016. http://188.190.33.55:7980/jspui/bitstream/123456789/336/1/ PB-25-15.pdf (дата звернення: 26.03.2020).

9. Kucher Oleg. (2017) Problems of management and marketing in the enterprises activity of agriculture, SCIENTIFIC ACHIEVEMENTS IN AGRICULTURAL ENGINEERING AGRONOMY AND VETERINARY MEDICINE Vol. 1, No. 1, pp. 31-41 ISBN 978-83-65180-17-9. 2017. http://188.190.33.55:7980/jspui/bitstream/123456789/12/1/Problems $\% 200 f \% 20$ Management $\% 20$ And\%20Marketing\%20In\%20Theenterprises\%20Activity\%20 Of\%20Agriculture.pdf (дата звернення: 26.03.2020).

10. Leftwich, R.W., Watts, R.L., \& Zimmerman, J.L. (1981). Voluntary corporate disclosure: The case of interim reporting. Journal of Accounting Research, 19, 50-77. 
11. Mandych O., Mykytas A., Melnyk M., Girzheva O., Kalinichenko S. (2020) Financial Condition of the Development of the Market of Renewable Energy Sources. In: Wróbel M., Jewiarz M., Szlęk A. (eds) Renewable Energy Sources: Engineering, Technology, Innovation. Springer Proceedings in Energy. Springer, Cham, pp. 939-951. https://link.springer.com/chapter/10.1007/978-3-03013888-2 90\#citeas (дата звернення: 28.03.2020).

12. Melnyk M., Zabolotnyy S. (2017) Essence of the financial state of the enterprise. Actual problems of agrarian economy: theory, practice, strategy. 2017 P. 262-265. http://188.190.33.55:7980/ jspui/bitstream/123456789/6916/1/120-123.pdf (дата звернення: 29.03.2020).

13. Morck, R., Yeung, B., \& Yu,W. (2000). The information content of stock markets: Why do emerging markets have synchronous stock price movements? Journal of Financial Economics, 58, 215-260.

14. Schipper, K. (1981). Discussion of voluntary corporate disclosure: The case of interim reporting. Journal of Accounting Research, 19, $85-88$.

15. Verrecchia, R.E. (1990). Information quality and discretionary disclosure. Journal of Accounting and Economics, 12, 365-380.
16. Yee, K.K. (2004). Interim reporting frequency and financial analysts' expenditures. Journal of Business Finance \& Accounting, 31, 167-198.

17. Zabolotnyy S., Melnyk M. (2018) The Financial Efficiency of Biogas Stations in Poland. In: Mudryk K., Werle S. (eds) Renewable Energy Sources: Engineering, Technology, Innovation. Springer Proceedings in Energy. Springer, Cham, pp. 83-93. https://link.springer.com/ chapter/10.1007/978-3-319-72371-6_9 (дата звернення: 27.03.2020).

18. Мельник М.I. (2017) Моделювання та оцінка фінансового стану сільськогосподарських агроформувань України та Польщі. Економічний вісник Запорізької державної 386 інженерної академії. 2017. Вип. 5(11). URL: http://www.visnyk.zdia.zp.ua/5-11-2017. (дата звернення: 27.03.2020)

19. Мельник M.I. (2017) Інноваційна привабливість України на основі "Global Innovation Index". Економічний вісник Запорізької державної інженерної академії. Запоріжжя. 2017. Вип. 4(10). C. $123-128$.

20. Чорний Г.М., Ястреб М.П., Кучер О.В. (2011) Новітній підхід до змісту управлінської діяльності в агроформуваннях. Аграрний інформаційний науково-виробничий журнал: наука і виробництво № 1-3. Київ. Агроінком. С. 80-84. 2011. http://library.tneu.edu.ua/ libsearch/page_lib.php (дата звернення: 26.03.2020).

Аннотация. С углублением реформ и быстрым развитием экономики Китая, китайский рынок привлекает предприятия из-за рубежа. Благодаря новой бизнес-модели, усовершенствованной философии бизнеса, отличному сервису и превосходному качеству, Starbucks завоевал хорошую репутацию среди китайских потребителей и получил высокий уровень прибыльности, и стал примером для многих предприятий данной сети. В статье рассмотрена финансовая деятельность компании Starbucks за последние пять лет в качестве основного объекта исследования и проведен анализ финансовой отчетности компании Starbucks в г. Chengdu с помощью базового метода финансового анализа. Анализ финансовой отчетности компании Starbucks г. Чэнду за последние пять лет показал, что хотя компания была прибыльной и создала хорошую репутацию всего за несколько лет, все еще есть некоторые проблемы в процессе деятельности, а именно проблемы в финансовом менеджменте. Поэтому учитывая эти проблемы выдвигаются предложения и перспективы на будущее.

Ключевые слова: Starbucks, финансовые показатели, расходы на расширение производства, диверсификация, методы финансового анализа, прибыль, налоги.

Анотація. 3 поглибленням реформ та швидким розвитком економіки Китаю, китайський ринок залучає підприємства 3-за кордону. Завдяки новій бізнес-моделі, вдосконаленій філософії бізнесу, відмінному сервісу та чудовій якості, Starbucks завоював хорошу репутацію серед китайських споживачів та отримав високий рівень прибутковості, та став прикладом для багатьох підприємств даної мережі. У жовтні 2013 року Центральне телебачення Китаю повідомило про несподівану прибутковість китайських ресторанів Starbucks. Згідно з доповіддю, репортери порівняли ціну латте Starbucks (354 мл) в Пекіні, Чикаго, Лондоні і Бомбеї. Ціна в Пекіні була найбільшою, а в Бомбеї найменшою. Згідно з доповідями, латте коштувало тільки 2 юаня (0,67 долара), але продажна ціна склала 27 юанів (4,5 долара) тому прибутковість в Китаї виявилася вищою, ніж в інших країнах. У статті визначено, що фінансовий результат діяльності окремого суб'єкта господарювання виступає як фактична, складна та багатовимірна категорія. Позитивний фінансовий результат є основною метою діяльності компанії на ринку та одним із ключових показників, що визначає ефективність ії роботи, служить джерелом платежів до бюджетів усіх рівнів, а також забезпечує розширене відтворення виробництва. У статті розглянуто фінансову діяльність компанії Starbucks за останні п'ять років як основний об'єкт дослідження та проведено аналіз фінансової звітності компанії Starbucks y м. Chengdu за допомогою базового методу фінансового аналізу. У статті також представлено відповідні методи аналізу фінансових звітів та загальну ситуацію компанії Starbucks, а також детально проаналізовано фінансовий звіт компанії Starbucks міста Chengdu за останні п’ять років. Аналіз фінансової звітності компанії Starbucks м. Ченду за останні п’ять років показав, що хоча компанія була прибутковою і створила хорошу репутацію лише за кілька років, все ще є деякі проблеми в процесі діяльності, а саме проблеми в фінансовому менеджменті. Фінансовий аналіз також показав низький рівень платоспроможності компанії в м. Ченду. Для вирішення цих проблем потрібно впровадити на підприємстві систему з коригування певних напрямів діяльності, які існують зараз у компанії Starbucks у місті Ченду, наприклад різноманітність та структура продукції поновлюються повільно, тому необхідно звернути увагу на вирішення даної проблеми. Тому з огляду на ці проблеми висуваються пропозиції та перспективи на майбутнє.

Ключові слова: Starbucks, фінансові показники, витрати на розширення виробництва, диверсифікація, методи фінансового аналізу, прибуток, податки. 